INTERNATIONAL DESIGN CONFERENCE - DESIGN 2018

https://doi.org/10.21278/idc.2018.0470

\title{
THE WORLD IS COMPLEX THEREFORE OUR RESEARCH IS NEEDED - USING DATA MINING FOR LITERATURE REVIEWS
}

\author{
A. Albers, N. Bursac, V. Butenko, F. Marthaler and Q. Zhang
}

\begin{abstract}
Using current data-mining technologies, we analyzed 3712 papers submitted from 2002-2017 at the International Conference on Engineering Design and International Design Conference. We have explored various research questions and propose an approach for analyzing a great number of papers on product engineering and use them for respective research. Here, we show examples of how data mining can be used to support the user in carrying out literature research. However, one is particularly clear: The user must always critically question the results with his intelligence in order to derive findings.
\end{abstract}

Keywords: data mining, big data analysis, complexity, literature research

\section{Introduction}

If you have the honor of regularly reviewing papers and research proposals, there is one thought that comes to mind: we as product engineering researchers are not too creative to come up with suitable introductions to our research papers. Many papers begin with the notion: "the world is so complex and in order to deal with it, we need our research".

Up to now it was tedious work to empirically confirm this impression and therefore not worth the effort. Thousands of papers would have to be read and analyzed to examine whether the notion would be repeated and, if so, how often. Thanks to modern analysis tools, this is no longer necessary. We can use data mining to analyze large data sets and draw conclusions for our research.

In this paper we consider two aspects. On the one hand, we would like to get to the bottom of the question, if this postulated standard introduction is actually often used, and on the other hand, we present an open source project that enables scientists to analyze large number of papers on product engineering and use them for their respective research.

\section{Background}

In the twenty-first century, text mining has become more and more popular due to the successful development of information technology. New technologies and software products open new possibilities to structure and analyze large data sets and help to interpret and understand them. In this chapter we will give an overview over the state of the art in text mining tools and methods for data analysis.

\subsection{Overview about current data mining software solutions}

There is already a lot of software on the market to assist researchers with qualitative and quantitative data analysis. Most applications offer important features for text analysis like the import of different 
range of data sources, coding of text and images as well as analysis tools that can represent information as meaningful diagrams, charts, or maps. They can help researchers in different situations with a quick search for relevant information, assist in coding, or in providing powerful analysis results. There are different applications available on the market such as RapidMiner, KNIME, Orange, MAXQDA, nVivo, Atlas, Dedoose, QDAMiner V5 etc. It is important to note, that the data preparation is very time-consuming and has major influence on the quality of analysis results. Therefore, several issues must be considered in order to choose the right software that is suitable for the analysis objectives. In the following a quick introduction to different text mining tools with their strengths and weaknesses will be presented.

RapidMiner is a popular free text and data mining tool, written by Java language. It provides some extensible data analysis and mining algorithm implementation, aiming at helping developers create intelligent applications more conveniently and more quickly. In addition to data mining, RapidMiner also provides functions such as data pre-processing and visualization, prediction analysis and statistical modeling.

KNIME (Konstanz Information Miner) is an open source data analysis, report and synthesis platform, written by Java. It has all data mining tools for data extraction, integration, processing, analysis, transformation and loading. In addition to that, it has a graphical user interface that can help users to easily connect nodes for data processing. It combines the various components of data mining and machine learning, which is very helpful for business intelligence and financial data analysis. Also, users can easily extend the KNIME by adding additional functionality at any time.

Orange is an open source data mining and machine learning tool, whose graphical environment is called the Orange canvas (Orange Canvas). Besides the advantages of friendly interface and ease of use, the strength of Orange lies in providing a large number of visualization methods, displaying data and models in various ways and searching for suitable visual forms intelligently to support the interactive exploration of data. In addition to that, it contains a complete set of components for data pre-processing and provides functions of data accounting, transition, modeling, pattern evaluation and exploration. In addition to the several open source data and text mining software mentioned above, there are many charged qualitative analysis software.

NVivo is a powerful qualitative analysis software solution, which can effectively analyze various types of data format, such as word, text, image, voice or video.

ATLAS.ti is a powerful and worktable tool for qualitative analysis of large volume text, image, audio and video data. This tool can organize, integrate and manage the information in a creative and systematic way. Dedoose is a software to analyze qualitative and mixed methods research. The data in form of text, photos, audio, videos, spreadsheets and more can be analyzed. It is more suitable for projects that require team work.

MAXQDA is a software for qualitative analysis from VERBI Company. With this software users can encode, classify, visualize, and share information from interviews, text, video or audio data. All most widespread languages are supported.

QDA-Miner V5 is a qualitative data analysis tool from Canadian Provalis Research Company. Small and large collections documents and images can be easily coded, annotated, retrieved, and analyzed. Furthermore, the data can be imported directly from web surveys platforms, social media, email providers or reference manager tools. Through powerful search functions such as keyword search, section retrieval, query by example with learn function etc., the analysis can be done faster and with less rework effort.

\subsection{Methods for text analysis}

Mabogunje et al. (2002) have analyzed 717 papers submitted from 1999-2001 at the International Conference on Engineering Design (ICED). The target was to improve the classification of papers and workshops at ICED conferences through establishing a profile for each paper and their association with relevant topics. For this purpose, the authors defined an ontology for product development processes and searched for specified words in the first few lines of all documents (for example, in the title), how frequently they occurred in all documents and the appearance of all defined specific words. An indexing tool was used for the analysis, which is utilized by major internet search engines. 
Elsevier's Analytical Services (2017) have analyzed in their study 53,633 publication (articles, reviews and conference proceedings) submitted from 2010-2015 by EPSRC (Engineering and Physical Sciences Research Council). The focus was on the analysis of bibliometric data based on advanced indicators such as field-weighted citation impact (FWCI), citation percentiles, collaboration of authors etc.

(Li et al., 2009) applied distribution of words in article titles, author keywords to evaluate trends in research topics. (Zhang et al., 2010) used certain words in the abstracts of papers to determine research trends. (Mao et al., 2010) applied a word cluster analysis to find the research hotspots for specific topics.

\section{Methodical approach}

According to the current state of research, there are various commercial tools for data mining and these can also be used for scientific analyses. However, such an approach has not yet been transferred to Design Society papers, thus it is not available for the analysis of research papers. Therefore, an approach is needed that is able to adopt this analysis software, in order to use it to review literature. Initially the analysis of the lines of argumentation in introductions should demonstrate the potential and subsequently be made available as a method of analysis. The following research questions are derived from these considerations:

1. What percentage of the papers on methods of development starts with the introduction that our research aims at coping with complexity?

2. How must the data be modeled so that such analyses can be answered with the help of data mining?

3. How can this data analysis approach be used to carry out further analyses in the context of product engineering?

First, a specific example is shown in order to provide the readers with all relevant information and to show the possibilities of data mining in an exemplary way. The findings of this specific example will be used in the next step to derive a data structure model accordingly. In the final step, the methodological procedure and the data structure model are evaluated using various examples.

For our analysis, we selected QDA-Miner V5 tool. It can process large quantities of files without having a system crash and find the data we need more effectively through its powerful search function. The important content can be automatically identified and easy coded. Through different add-on softwares, the data can be effectively analyzed and organized. Besides, there are many ways to visualize the data in order to understand difficult interrelations.

The papers of the ICED and DESIGN conferences of the last 15 years were uploaded. A total of 3712 papers were analyzed. The distribution is shown in Figure 1.

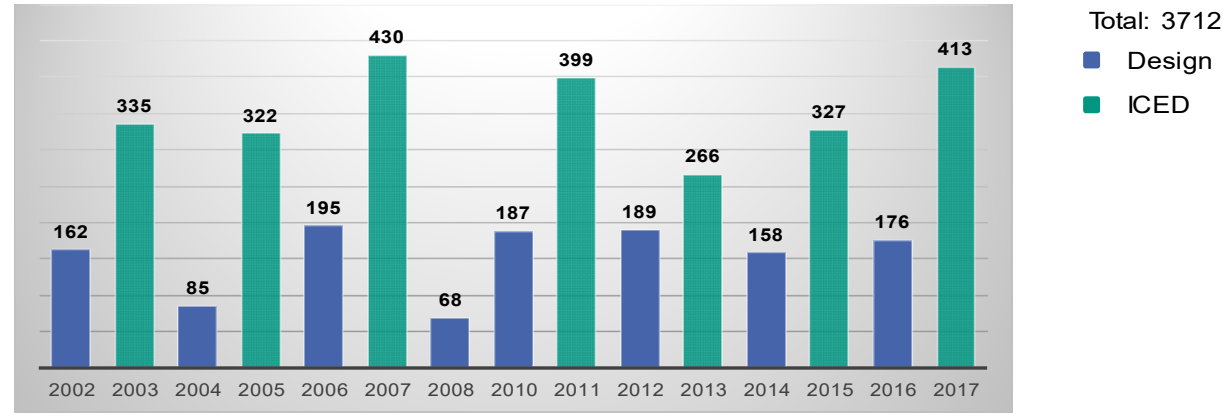

Figure 1. Number of uploaded publications for analysis with data mining

Only the papers of the year 2009 could not be uploaded. There were problems with formatting. As the central conferences of the Design Society the conferences ICED and DESIGN were chosen, since many results and a relatively broad research of product engineering are published in the scope of these events. An empirically sufficient number of papers was analyzed. The analysis of 3712 papers produced valid results in the population of the Design Society Paper. 


\section{Results}

\subsection{Analysis of the ICED and DESIGN papers introduction}

In the analysis of the 3712 papers of the ICED and DESIGN conferences since 2002, it was found that in chapter 1 in 1337 papers the term complex is mentioned. Many papers start with an observation that is presented as change at the time: "The automotive industry is in a period of upheaval". However, the analysis of the development over time shows that the progression has remained almost constant over the last 15 years (see Figure 2). It also shows that if everyone always uses complexity as a justification, this does not make differentiation possible.

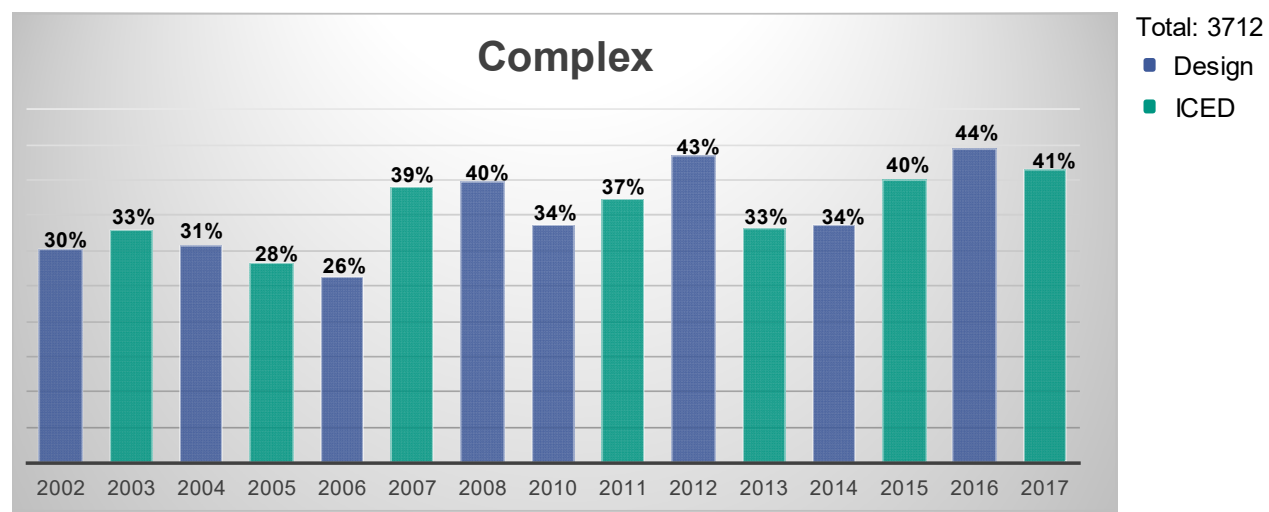

Figure 2. Percentage number of papers of a conference, that mentions complexity in the introduction

So it seems to be a recurring thought that is well known to readers and reviewers. Analyzing the list of potential reviewers under the assumption that reviewers themselves have written at least 5 papers at the Design Society's central conferences before they work as reviewers. This leaves 171 authors of the conferences. Of these people, $92 \%$ have themselves once chosen the argument of complexity in their introduction. Figure 3, for example, lists the 20 authors with the most publications. All these authors have already stated this thought in the introduction, as well.

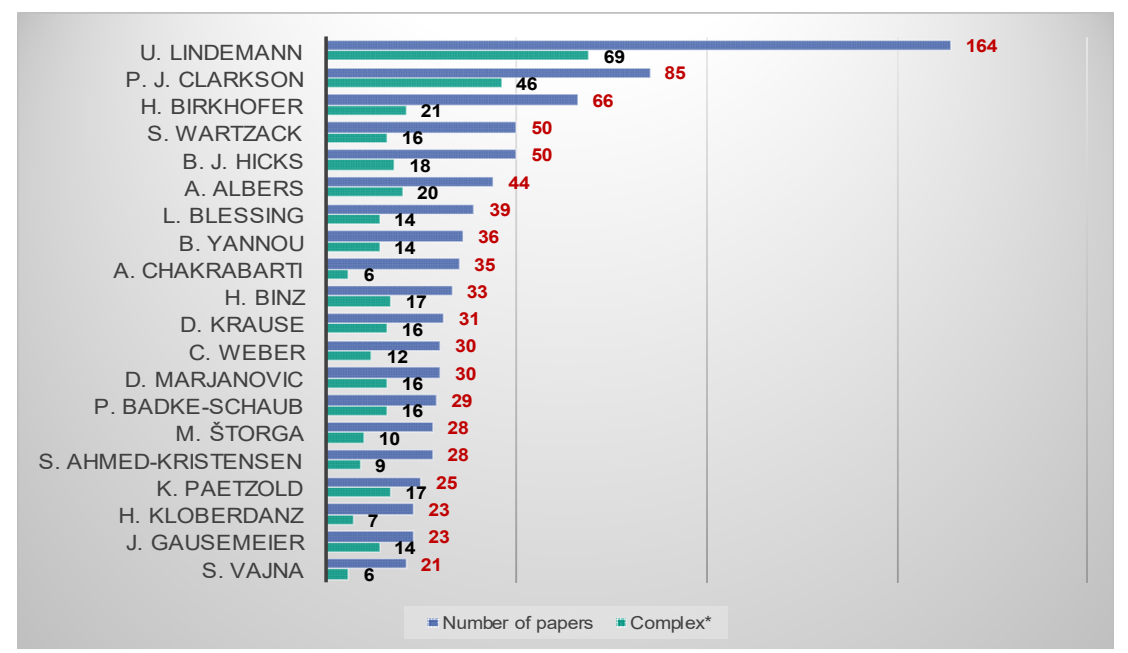

Figure 3. 20 authors with the most publications at the ICED and Design Conference since 2002 and mentioning of complexity in introduction

It seems to be a well-known phenomenon. Nevertheless, a lot of space and time is used for this. Figure 4 shows the length of the different introductions. Thus, most papers have between 201 and 400 words and the average introduction of ICED and DESIGN conferences contains 475 words. 


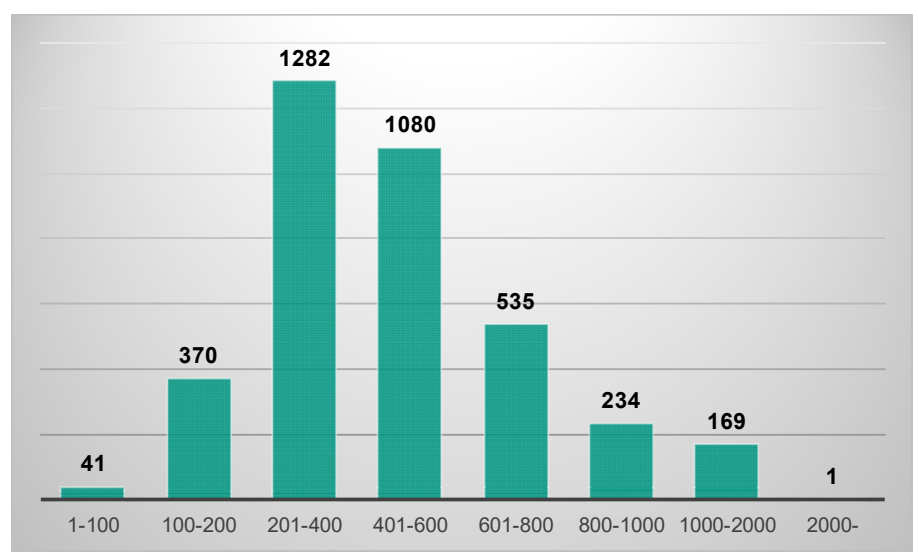

Figure 4. Clustered number of publications according to length of introduction

If you line up all the introductions that mention this thought, it results in more than 600,000 words. This draws up resources for writing and reading. The question arises as to how these resources can be better used in the context of introductions. Here are some examples that can be used as alternative introductions: 1) Tell a story; 2) Use a picture; 3) Describe the failure of a product; 4) Present a future scenario; 5) Use an optical illusion; 6) Tell an anecdote; 7) Show a paradox; 8) Make use of analogies However, if it is to be the usual introduction, we would suggest the following short, space-saving sentence for future introductions: Like in $35 \%$ of the papers published in our community: The world is complex, therefore our research is needed.

\subsection{Methodology to analyze conference papers using QDA-Miner}

In order to answer defined research questions in Chapter 3, 3712 publications from ICED and DESIGN Conferences should be prepared for the analyses. The analysis consists of six main steps (see Figure 5). First the structure of the two conference papers is analyzed. It turns out that the two conferences have the same structure. Thus, the conference name, year and location are at the top, followed by the title of the publication, author, abstract and keywords.

Next, the goals of the analysis have to be defined. It is important to consider as early as possible which questions should be answered by the analyses, so that the data can be prepared accordantly. For example the targets in the previous chapter were:

1. Determine $\%$ of paper with the word complexity in introduction

2. Determine average number of words in introduction

3. Determine 20 authors who have published the most and how often they used complexity in introductions

Once the goals are set, the variables and text passages required for the analysis can be identified. In our case the variables year, place and conference title and as text passages title of the paper, author, abstract, keywords, introduction and references were identified. Furthermore in this case one goal was to look for the occurrence of the word "complexity" in introductions, therefore it is necessary to encode this chapter properly. QDA-Miner offers a helpful function with which certain text digits could be coded automatically. However, therefore the signal word has to be unambiguously identified and all publications have to use the same words for the first and second chapters, which cannot be assumed. Therefore, all papers are prepared accordingly in the next step before importing them into QDA-Miner. By using visual basic application (VBA) specific symbols ("++1++") before chapter one and ("++2++") before chapter two were added.

After the successful import of all publications into QDA-Miner all relevant text passages and variable texts can be encoded by using different software functionalities. After each search, it is important to check the results briefly for quality, so that the analysis is not subsequently influenced. As soon as all necessary content is encoded, analyses can be carried out in the next step. By using the function called "Analyze", those variables and codes can be for example visualized as bubble charts or heat maps. 


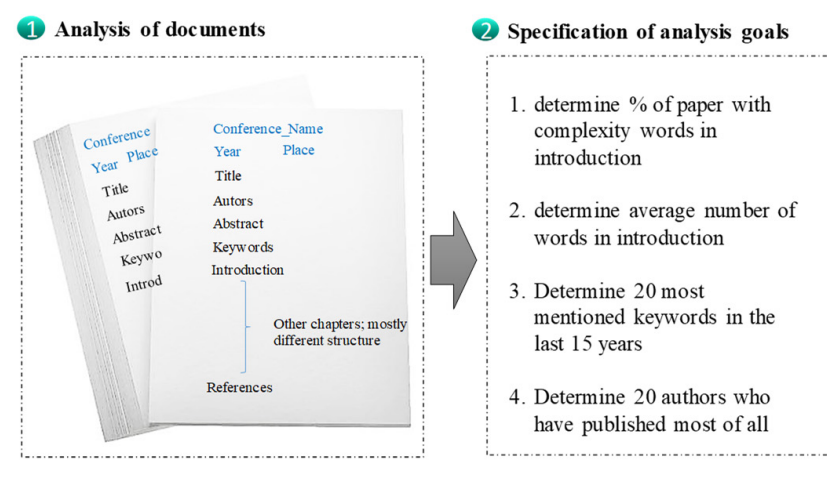

(3) Determining of variables and important text passages

(6) Evaluation and interpretation

5 Coding of variables and text passages
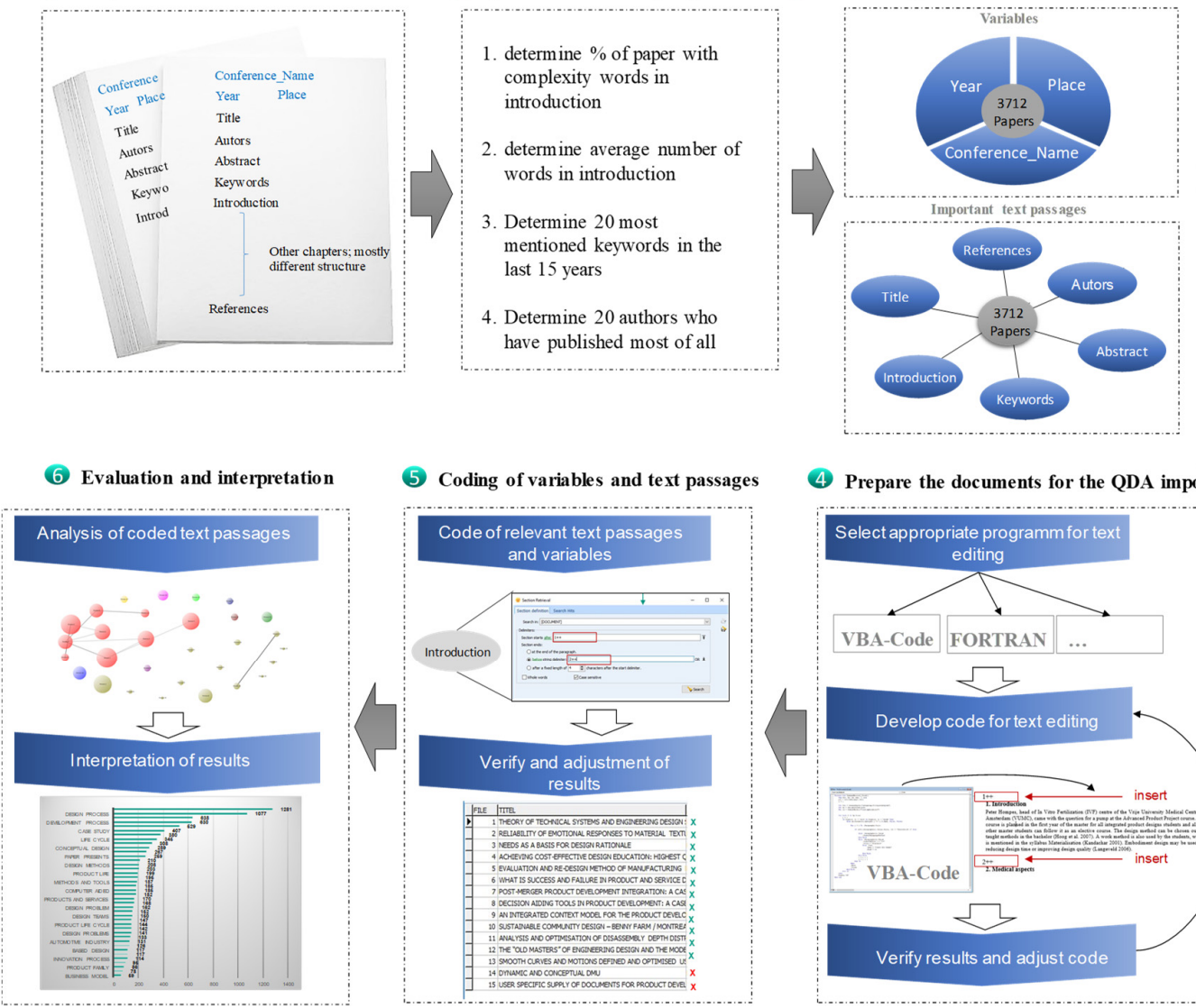

(4) Prepare the documents for the QDA import

Figure 5. Six steps for analyzing of conference papers

\subsection{Analyses with data mining}

Once the data has been imported into the model, further analyses can be carried out with little effort. In the following, individual examples will be presented in order to introduce starting points for possible analyses. These can be of a general nature, such as identifying the most popular keywords at conferences. These are shown as examples in Figure 6.

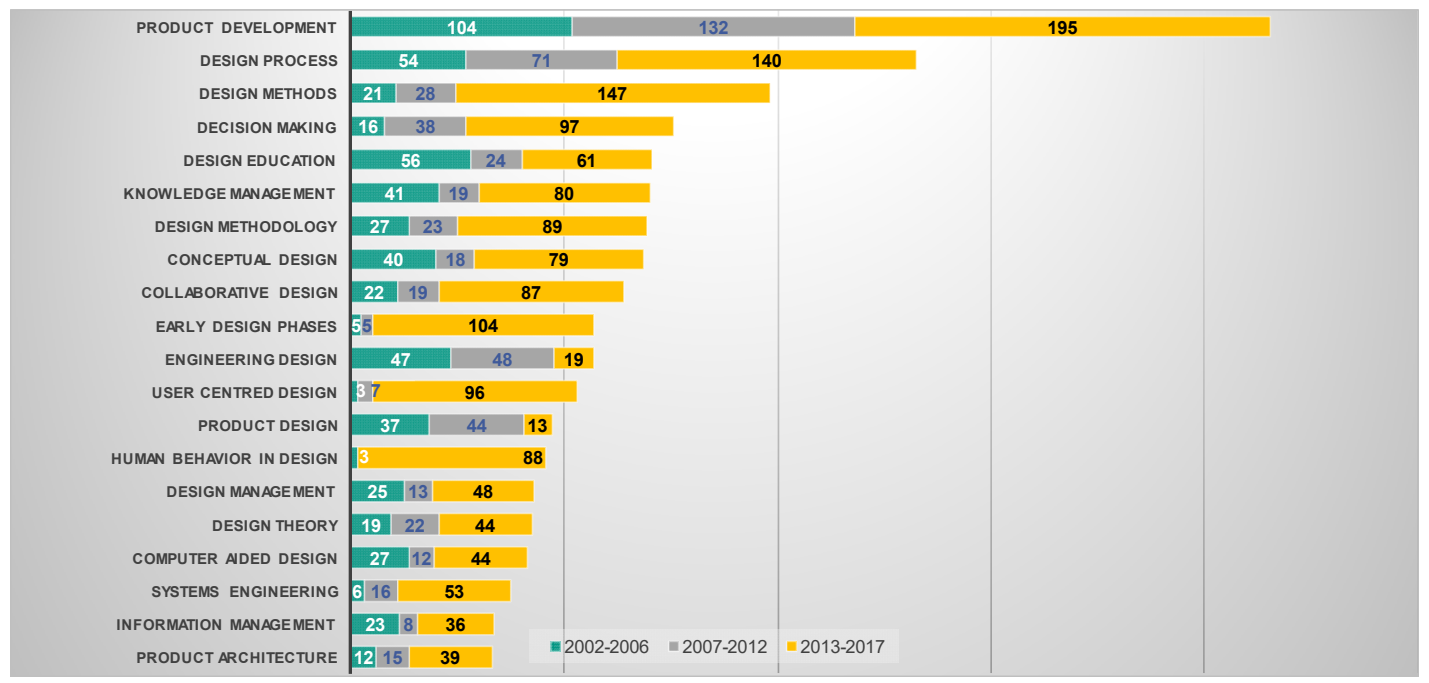

Figure 6. Most popular keywords at conferences 
It becomes apparent that product development is a common but probably relatively general keyword and that the development of specific systems is not so much the focus of research, although research on real world problems is especially important for the validation of methods.

In addition to general analyses such as finding keywords or references in introductions, the approach can also be used to support specific research projects. The approach is illustrated below using an example from our current research. The InnoFox (Albers et al., 2015) application for situation-specific recommendations for methods has been developed in recent years. Processes in companies were analyzed manually; various methods were identified, clustered and empirically verified on the basis of literature research. The following paragraph illustrates how these methods could have been identified more efficiently using data mining. For this purpose, the approach shown in Figure 7 is suitable.
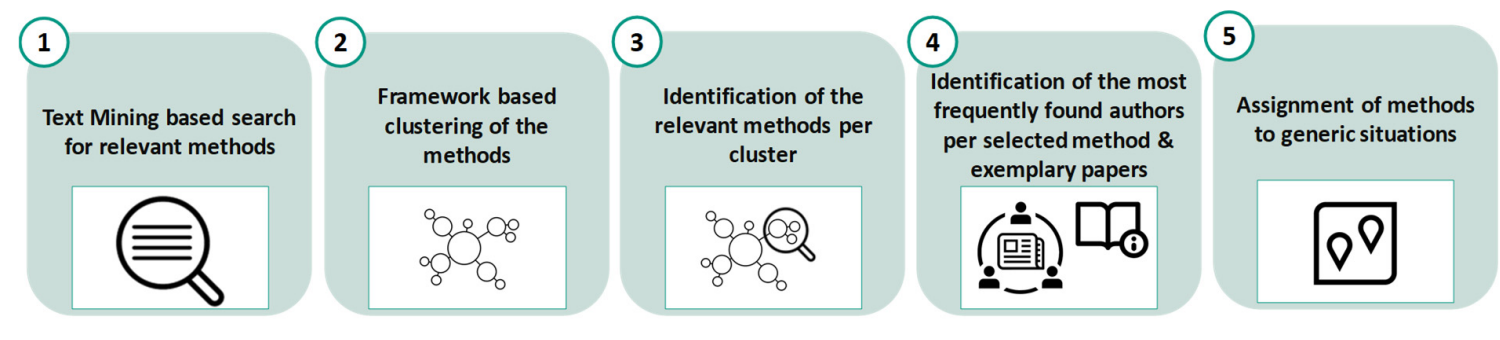

Figure 7. Methodical approach for a data mining based literature research on development methods

In the first step, all papers are scanned for methods using Text Mining. The result represents an unordered list of all methods mentioned. Following (Albers et al., 2014), the methods are clustered using the framework: Analysis methods, Creativity methods, Evaluation methods, Planning and control methods, Methods for rework and learn. In the next step, the three most frequently mentioned methods of the respective cluster are identified in order to integrate a representative number of interesting sources into the further selection process. The fourth step represents the identification of the three most active authors in this context and to find exemplary papers. The fifth step is to allocate the exemplary methods to generic situations of product engineering following the 12 macro activities of the IPEM - Integrated Product Engineering Model: Project planning, Validation and verification, Knowledge management, Change management, Product Profile detection, Product Idea detection, Modelling of principle solution and embodiment, Prototype building, Production, Market launch, Analysis of Utilization, Analysis of Decommission. Figure 8 shows the result of the fourth step of these Data Mining analyses. The three most frequently used methods per cluster are applied vertically. The three most active authors with exemplary papers for each method complete the table horizontally. Moreover, this graphic can serve as a starting point for further literature analysis, similar to the literature review paper. With this data mining-based selection, the researcher has a manageable number of interesting methods and exemplary papers for manual review.

In the context of the Innofox, it was particularly interesting to see which of these methods can be used in which situation. As a framework for describing the situations, the IPEM - Integrated Product Engineering Model is used. For this purpose, all methods had to be analyzed in detail and allocated to the generic situations (see Figure 9). With the help of data mining, however, an automated analysis can now be carried out by semantic assignment. Hence, additional semantic elements, such as customer-relaxance or market situation have been added for example to the activity Product Profile detection. In this way, an initial classification for the Innofox could already have been carried out with the help of data mining. This would have saved a lot of time. This approach can be applied to a variety of questions and can contribute to efficiently narrow down topics. 


\begin{tabular}{|c|c|c|c|c|}
\hline & $\begin{array}{c}\text { Total Number } \\
\text { of found } \\
\text { papers }\end{array}$ & $\begin{array}{c}\text { Author } 1 \\
\text { (number of papers \& } \\
\text { example papers) }\end{array}$ & $\begin{array}{c}\text { Author } 2 \\
\text { (number of papers \& } \\
\text { example papers) }\end{array}$ & $\begin{array}{c}\text { Author } 3 \\
\text { (number of papers \& } \\
\text { example papers) }\end{array}$ \\
\hline \multicolumn{5}{|l|}{ Analysis methods } \\
\hline $\begin{array}{l}\text { Quality Function } \\
\text { Deployment }\end{array}$ & 224 & $\begin{array}{l}\text { U. Lindemann (13), e.g. } \\
\text { (Lindemann et al., 2016) }\end{array}$ & $\begin{array}{l}\text { H. Birkhofer (10), e.g. } \\
\text { (Zier and Birkhofer, } \\
\text { 2013) }\end{array}$ & $\begin{array}{l}\text { T. Sakao (8), e.g. } \\
\text { (Sakao et al., 2005) }\end{array}$ \\
\hline $\begin{array}{c}\text { Finite element } \\
\text { method }\end{array}$ & 66 & $\begin{array}{l}\text { A. Albers (2), e.g. } \\
\text { (Albers et al., 2007) }\end{array}$ & $\begin{array}{l}\text { M. Lotz (2), e.g. } \\
\text { (Lotz et al., 2005) }\end{array}$ & $\begin{array}{l}\text { M. Steinert (2), e.g. } \\
\text { (Steinert et al., 2015) }\end{array}$ \\
\hline $\begin{array}{c}\text { Contact and } \\
\text { Channel }\end{array}$ & 22 & $\begin{array}{l}\text { A. Albers (12), e.g. } \\
\text { (Albers et al., 2011) }\end{array}$ & $\begin{array}{l}\text { N. Burkardt (3), e.g. } \\
\text { (Burkardt et al., 2005) }\end{array}$ & $\begin{array}{l}\text { H. Binz (1), e.g. } \\
\text { (Binz et al., 2015) }\end{array}$ \\
\hline \multicolumn{5}{|l|}{ Creativity methods } \\
\hline TRIZ & 238 & $\begin{array}{l}\text { U. Lindemann (11), e.g. } \\
\text { (Lindemann et al., 2016) }\end{array}$ & $\begin{array}{l}\text { F. Rotini (9), e.g. } \\
\text { (Rotini et al., 2016) }\end{array}$ & $\begin{array}{l}\text { Y. Reich (5), e.g. } \\
\text { (Reich et al., 2003) }\end{array}$ \\
\hline User experience & 186 & $\begin{array}{c}\text { U. Lindemann (7), e.g. } \\
\text { (Lindemann and } \\
\text { Michailidou, 2016) }\end{array}$ & $\begin{array}{c}\text { C. Kim (4), e.g. } \\
\text { (Kim and Cho, 2017) }\end{array}$ & $\begin{array}{l}\text { P. Childs (3), e.g. } \\
\text { (Childs et al., 2017) }\end{array}$ \\
\hline Open innovation & 101 & $\begin{array}{l}\text { U. Lindemann (15), e.g. } \\
\text { (Lindemann and } \\
\text { Boehmer, 2015) }\end{array}$ & $\begin{array}{l}\text { A. Ekman (2), e.g. } \\
\text { (Ekman et al., 2011) }\end{array}$ & $\begin{array}{l}\text { C. Hollauer (2), e.g. } \\
\text { (Hollauer et al., 2017) }\end{array}$ \\
\hline \multicolumn{5}{|l|}{ Evaluation methods } \\
\hline \begin{tabular}{|c|} 
Life Cycle \\
Assessment \\
\end{tabular} & 136 & $\begin{array}{l}\text { H. Birkhofer (8), e.g. } \\
\text { (Birkhofer et al., 2004) }\end{array}$ & $\begin{array}{l}\text { A. Chakrabarti (6), e.g. } \\
\text { (Chakrabarti et al., 2015) }\end{array}$ & $\begin{array}{c}\text { F. Vallet (5), e.g. } \\
\text { (Vallet et al., 2017) }\end{array}$ \\
\hline Risk Analysis & 110 & $\begin{array}{l}\text { H. Birkhofer (3), e.g. } \\
\text { (Birkhofer et al., 2011) }\end{array}$ & \begin{tabular}{|c|} 
A. Bohn (3), e.g. \\
(Bohn et al., 2011) \\
\end{tabular} & $\begin{array}{l}\text { R. Engelhardt (3), e.g. } \\
\text { (Engelhardt et al., 2011) }\end{array}$ \\
\hline Virtual prototyping & 79 & $\begin{array}{l}\text { J. Gausemeier (6), e.g. } \\
\text { (Gausemeier et al., } \\
\text { 2004) }\end{array}$ & $\begin{array}{l}\text { I. Horváth (5), e.g. } \\
\text { (Horvath, 2011) }\end{array}$ & $\begin{array}{l}\text { C. Weber (4), e.g. } \\
\text { (Weber et al., 2012) }\end{array}$ \\
\hline \multicolumn{5}{|c|}{ Planning and control methods } \\
\hline Design for $X$ & 301 & $\begin{array}{l}\text { U. Lindemann (17), e.g. } \\
\text { (Lindemann and Nissl, } \\
\text { 2005) }\end{array}$ & $\begin{array}{c}\text { S. Wartzack (14), e.g. } \\
\text { (Wartzack and } \\
\text { Schleich, 2013) }\end{array}$ & $\begin{array}{l}\text { D. Krause (11), e.g. } \\
\text { (Krause and Ripperda, } \\
\text { 2014) }\end{array}$ \\
\hline Modularization & 225 & $\begin{array}{l}\text { D. Krause (21), e.g. } \\
\text { (Krause and Eilmus, } \\
\text { 2011) }\end{array}$ & $\begin{array}{l}\text { U. Lindemann (19), e.g. } \\
\text { (Lindemann, 2007) }\end{array}$ & $\begin{array}{l}\text { H. Birkhofer (15), e.g. } \\
\text { (Birkhofer et al., 2003) }\end{array}$ \\
\hline $\begin{array}{l}\text { Design for } \\
\text { environment }\end{array}$ & 106 & $\begin{array}{l}\text { H. Birkhofer (11), e.g. } \\
\text { (Birkhofer and Ernzer, } \\
\text { 2003) }\end{array}$ & $\begin{array}{c}\text { C. Amaresh (3), e.g. } \\
\text { (Amaresh and Srinivas, } \\
\text { 2007) }\end{array}$ & $\begin{array}{l}\text { F. Vallet (2), e.g. } \\
\text { (Vallet et al., 2015) }\end{array}$ \\
\hline \multicolumn{5}{|c|}{ Methods for rework and learn } \\
\hline $\begin{array}{l}\text { Knowledge } \\
\text { engineering }\end{array}$ & 104 & $\begin{array}{l}\text { M. P. Weiss (3) , e.g. } \\
\text { (Weiss et al., 2004) }\end{array}$ & $\begin{array}{c}\text { U. Lindemann (2), e.g. } \\
\text { (Lindemann et al., 2017) }\end{array}$ & $\begin{array}{l}\text { Bergsjö Dag (2), e.g. } \\
\text { (Bergsjö et al., 2017) }\end{array}$ \\
\hline Knowledge Gap & 30 & $\begin{array}{l}\text { D. Bergsjö (3), e.g. } \\
\text { (Bergsjö et al., 2017) }\end{array}$ & $\begin{array}{c}\text { A. Hari (2), e.g. } \\
\text { (Weiss and Hari, 2003) } \\
\end{array}$ & $\begin{array}{l}\text { M. P. Weiss (2), e.g. } \\
\text { (Weiss et al., 2002) }\end{array}$ \\
\hline Matrix organization & 14 & $\begin{array}{l}\text { M. Norell (3), e.g. } \\
\text { (Norell et al., 2003) }\end{array}$ & $\begin{array}{l}\text { J. Pilemalm (1), e.g. } \\
\text { (Pilemalm and Velin, } \\
\text { 2003) }\end{array}$ & $\begin{array}{l}\text { M. Löwer (1), e.g. } \\
\text { (Löwer, 2017) }\end{array}$ \\
\hline
\end{tabular}

Figure 8. Most frequently mentioned methods per cluster and most active authors in this area with exemplary papers 


\begin{tabular}{|c|c|c|c|c|c|c|c|c|c|c|c|c|}
\hline & $\begin{array}{l}\text { 일 } \\
\text { 들 } \\
\frac{0}{0} \\
\frac{0}{0} \\
\frac{\Phi}{0} \\
\frac{0}{0}\end{array}$ & 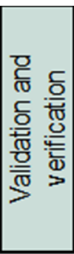 & 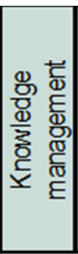 & 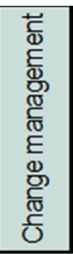 & 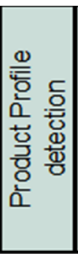 & 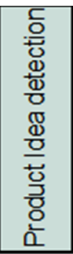 & 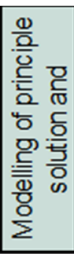 & 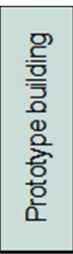 & $\begin{array}{l}\text { 듬 } \\
\text { 음 } \\
\text { 은 }\end{array}$ & 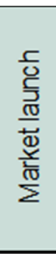 & 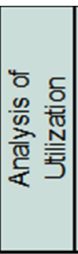 & 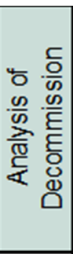 \\
\hline \multicolumn{13}{|l|}{ Analysis methods } \\
\hline Quality Function Deployment & $16 \%$ & $2 \%$ & $0 \%$ & $23 \%$ & $30 \%$ & $12 \%$ & $0 \%$ & $1 \%$ & $10 \%$ & $0 \%$ & $5 \%$ & $0 \%$ \\
\hline Finite element m ethod & $9 \%$ & $6 \%$ & $4 \%$ & $40 \%$ & $4 \%$ & $17 \%$ & $0 \%$ & $9 \%$ & $6 \%$ & $0 \%$ & $6 \%$ & $0 \%$ \\
\hline Contact and Channel & $15 \%$ & $3 \%$ & $2 \%$ & $42 \%$ & $10 \%$ & $16 \%$ & $0 \%$ & $1 \%$ & $9 \%$ & $0 \%$ & $0 \%$ & $0 \%$ \\
\hline \multicolumn{13}{|l|}{ Creativity methods } \\
\hline TRIZ & $13 \%$ & $2 \%$ & $2 \%$ & $26 \%$ & $17 \%$ & $25 \%$ & $0 \%$ & $2 \%$ & $8 \%$ & $0 \%$ & $4 \%$ & $0 \%$ \\
\hline User experience & $14 \%$ & $3 \%$ & $1 \%$ & $24 \%$ & $24 \%$ & $14 \%$ & $0 \%$ & $11 \%$ & $4 \%$ & $0 \%$ & $5 \%$ & $0 \%$ \\
\hline Open innovation & $11 \%$ & $2 \%$ & $4 \%$ & $24 \%$ & $25 \%$ & $19 \%$ & $1 \%$ & $5 \%$ & $5 \%$ & $0 \%$ & $5 \%$ & $0 \%$ \\
\hline \multicolumn{13}{|l|}{ Evaluation methods } \\
\hline Life Cycle Assessment & $13 \%$ & $1 \%$ & $1 \%$ & $21 \%$ & $15 \%$ & $15 \%$ & $0 \%$ & $2 \%$ & $30 \%$ & $0 \%$ & $3 \%$ & $0 \%$ \\
\hline Risk Analysis & $25 \%$ & $3 \%$ & $1 \%$ & $28 \%$ & $19 \%$ & $10 \%$ & $1 \%$ & $5 \%$ & $8 \%$ & $0 \%$ & $2 \%$ & $0 \%$ \\
\hline Virtual prototyping & $12 \%$ & $3 \%$ & $1 \%$ & $19 \%$ & $11 \%$ & $11 \%$ & $1 \%$ & $33 \%$ & $6 \%$ & $0 \%$ & $3 \%$ & $0 \%$ \\
\hline \multicolumn{13}{|l|}{ Planning and control methods } \\
\hline Design for $\mathrm{X}$ & $14 \%$ & $1 \%$ & $2 \%$ & $28 \%$ & $19 \%$ & $14 \%$ & $0 \%$ & $2 \%$ & $16 \%$ & $0 \%$ & $4 \%$ & $0 \%$ \\
\hline Modularization & $17 \%$ & $2 \%$ & $1 \%$ & $25 \%$ & $20 \%$ & $14 \%$ & $0 \%$ & $2 \%$ & $13 \%$ & $0 \%$ & $5 \%$ & $0 \%$ \\
\hline Design for environment & $13 \%$ & $0 \%$ & $1 \%$ & $22 \%$ & $20 \%$ & $12 \%$ & $0 \%$ & $2 \%$ & $24 \%$ & $0 \%$ & $4 \%$ & $0 \%$ \\
\hline \multicolumn{13}{|l|}{ Methods for rework and learn } \\
\hline Knowledge engineering & $6 \%$ & $5 \%$ & $15 \%$ & $37 \%$ & $9 \%$ & $16 \%$ & $0 \%$ & $4 \%$ & $7 \%$ & $0 \%$ & $2 \%$ & $0 \%$ \\
\hline Knowledge Gap & $16 \%$ & $2 \%$ & $5 \%$ & $21 \%$ & $30 \%$ & $9 \%$ & $2 \%$ & $5 \%$ & $9 \%$ & $0 \%$ & $0 \%$ & $0 \%$ \\
\hline Matrix organization & $19 \%$ & $5 \%$ & $3 \%$ & $22 \%$ & $14 \%$ & $14 \%$ & $0 \%$ & $0 \%$ & $16 \%$ & $0 \%$ & $8 \%$ & $0 \%$ \\
\hline
\end{tabular}

Figure 9. Method classification in the macro activities of the IPEM

\section{Discussion and outlook}

The exemplary analysis of our introductions is not without irony. Nevertheless, the paper shows what new possibilities data mining opens up for the type of our literature analyses. For the use of data mining techniques in the context of literature analyses, we would like to draw your attention to the necessary preparatory work, the definition of research questions as well as the continuous and critical discussion of the results. It should be emphasized that a series of time-consuming preparatory works is required to carry out analyses of this kind. This preparatory work ranges from the acquisition of the required data sets, their preparation and formatting as well as the development of a corresponding data model, which is suitable for analysis. In addition, it is particularly beneficial to define the research questions to be answered at an early stage, since this enables a purpose-oriented structure of the data model and useless preparatory work can be reduced. Another aspect for the use of data mining is the continuous and critical interpretation of the generated results by the intelligent user. Overall, comparative data should be used to examine the fundamental validity of the analyzed data. Here, too, however, is the focus on the aim of the research: If, for example, only qualitative statements on wider trends are to be derived, small deviations between the data sets are acceptable in order to guarantee a corresponding cost-benefit ratio. With his intelligence, it is the essential task of the user to ensure the necessary quality of the data. In addition, the intelligence of the user is particularly important for interpreting the results of the data mining analyses: The generated results must always be placed in the context of the use case in order to derive specific findings and make them available for further use. For example, the introductory example looked for the word complexity in introductions. This does not necessarily mean that the line of argumentation followed our assumption. The use of this approach would also have shown, for example, that this paper uses the word complexity in the introduction. Such deviations must, of course, be taken into account and assessed against the background of their purpose. On the whole, these findings motivate further research work in the field of text mining. In the next step, we want to develop a new method that supports the user, as a central, intelligent element of the analyses, in the use of Data Mining.

Specifically, a supporting tool is to be provided to the user, which will make the use of Data Mining more efficient and effective. Corresponding approaches for this are the systematic derivation of research questions, the structured modeling of the data model as well as a leading process for critical discussion 
of the results in order to be able to derive specific findings. Together as a community, the in this way developed research method can be used and further developed in the medium term in order to obtain a targeted and significantly more efficient overview of current research in progress. Authors can be further assigned, additional conferences and journals can be added or country-specific versions of the data set can be created. The long-term goal is to provide a value-added research method and research database for product engineering by using open source. With the help of such an approach, the researcher cannot, of course, be relieved of the work of reading the papers. However, it is precisely the finding of really interesting literature that demands many man-hours. Therefore, the approach should be used to make the search for suitable literature, its evaluation and summary more effective and efficient. The used method was applied for the first time and therefore needs to be improved iteratively. This will be shown in the Future Works.

\section{References}

Al Maghraoui, O., Vallet, F., Puchinger, J. and Yannou, B. (2017), "Framing key concepts to design a human centered urban mobility system", Proceedings of ICED'17 / the 21 International Conference on Engineering Design, Vol. 3, Vancouver, Canada, August 21-25, 2017, The Design Society, Glasgow, pp. 91-100.

Albers, A., Burkardt, N. and Ohmer, M. (2005), "Approaches for synthesis of technical systems within the contact and channel model C\&CM", Proceedings ICED'05 / the $15^{\text {th }}$ International Conference on Engineering Design, Melbourne, Australia, August 15-18, 2005.

Albers, A., Hans-Georg, E., Thomas, M. and Helge, W. (2007), "Robust Design processes with CAD based finite element models", Proceedings of the ICED'07 / the $16^{\text {th }}$ International Conference on Engineering Design, Paris, France, August 28-31, 2007, The Design Society.

Albers, A., Martin, P. and Lorentz, B. (2011), "Modeling and design of contacts in electrical connectors", Proceedings of ICED'11 / the $18^{\text {th }}$ International Conference on Engineering Design, Vol. 4: Product and Systems Design, Copenhagen, Denmark, August 15-19, 2011, The Design Society, Glasgow, pp. 268-277.

Albers, A., Reiß, N., Bursac, N., Urbanec, J. and Lüdcke, R. (2014), "Situation-appropriate method selection in product development process - empirical study of method application", Proceedings of NordDesign 2014, The Design Society, Glasgow, pp. 550-559.

Albers, A., Reiß, N., Bursac, N., Walter, B. and Gladysz, B. (2015), "InnoFox-Situationsspezifische Methodenempfehlung im Produktentstehungsprozess", Proceedings of the Stuttgarter Symposium für Produktentwicklung (SSP), Fraunhofer Verlag, Stuttgart.

Balters, S., Bisballe Jensen, M. and Steinert, M. (2015), "Physiology and sensorial based quantification of humanobject interaction - the QOSI matrix", Proceedings of ICED'15 / the $20^{\text {th }}$ International Conference on Engineering Design, Vol. 11, Milan, Italy, July 27-30, 2015, The Design Society, Glasgow, pp. 121-132.

Benta, C., Wilberg, J., Hollauer, C. and Omer, M. (2017), "Process model for data-driven business model generation", Proceedings of ICED'17 / the 21 ${ }^{\text {st }}$ International Conference on Engineering Design, Vol. 2, Vancouver, Canada, August 21-25, 2017, The Design Society, Glasgow, pp. 347-356.

Boehmer, A. I. and Lindemann, U. (2015), "Open Innovation Ecosystem: Towards collaborative innovation", Proceedings of ICED'15 / the 20 th International Conference on Engineering Design, Vol. 8, Milan, Italy, July 2730, 2015, The Design Society, Glasgow, pp. 31-40.

Cho, K. and Kim, C. (2017), "Design for privacy in public space", Proceedings of ICED'17 / the $21^{\text {st }}$ International Conference on Engineering Design, Vol. 5, Vancouver, Canada, August 21-25, 2017, The Design Society, Glasgow, pp. 239-248.

Dick, M., Dewulf, W., Birkhofer, H. and Duflou, J. (2004), "Estimating the environmental impacts of similar products", Proceedings of DESIGN 2004 / the $8^{\text {th }}$ International Design Conference, Dubrovnik, Croatia, pp. 1515-1520.

Eifler, T., Mathias, J., Engelhardt, R., Kloberdanz, H., Birkhofer, H. and Bohn, A. (2011), "Evaluation of solution variants in Conceptual Design by means of adequate Sensitivity indices", Proceedings of ICED'11 / the $18^{\text {th }}$ International Conference on Engineering Design, Vol. 9, Copenhagen, Denmark, August 15-19, 2011, The Design Society, Glasgow, pp. 314-323.

Ekman, S., Ekman, A., Salunkhe, U. and Agarwal, A. (2011), "Design inspired innovation for rural India", Proceedings of ICED'11 / the $18^{\text {th }}$ International Conference on Engineering Design, Vol. 2, Copenhagen, Denmark, August 15-19, 2011, The Design Society, Glasgow, pp. 120-129.

Elsevier's Analytical Services (2017), Analysis of publications arising from research funded by the engineering and physical sciences research council. [online] Elsevier B.V. Available at: https:/www.epsrc.ac.uk/newsevents/pubs/publicationsanalysis/ 
Engelhardt, R., Wiebel, M., Eifler, T., Kloberdanz, H., Birkhofer, H. and Bohn, A. (2011), “UMEA-A follow up to analyse uncertainties in technical systems", Proceedings of ICED'11 / the $18^{\text {th }}$ International Conference on Engineering Design, Vol. 9, Copenhagen, Denmark, August 15-19, 2011, The Design Society, Glasgow, pp. $257-$ 266.

Engelhardt, R.A., Eifler, T., Mathias, J., Kloberdanz, H., Birkhofer, H. and Bohn, A. (2011), "Linkage of Methods Within the Umea Methodology-an Approach To Analyse Uncertainties in the Product Development Process", Proceedings of ICED'11 / the $18^{\text {th }}$ International Conference on Engineering Design, Vol. 10, Copenhagen, Denmark, August 15-19, 2011, The Design Society, Glasgow, pp. 433-442.

Engwall, M., Forslin, J., Kaulio, M., Norell, M. and Ritzén, S. (2003), "Engineering management for integration", Proceedings of ICED'03 / the 14 ${ }^{\text {th }}$ International Conference on Engineering Design, Stockholm, August 19-21, 2003.

Ernzer, M. and Birkhofer, H. (2003), "Environmental impact assessment in design or is it worth to carry out a full LCA", Proceedings of ICED'03 / the $14^{\text {th }}$ International Conference on Engineering Design, Stockholm, August 19-21, 2003.

Fargnoli, M., Sakao, T. and Notarnicola, S. (2005), "A procedure to identify effective redesign options in eco-design", Proceedings of ICED'05 / the 15 International Conference on Engineering Design, Melbourne, Australia, August 15-18, 2005.

Frillici, F.S., Rotini, F. and Fiorineschi, L. (2016), "Re-Design the design task through TRIZ tools", Proceedings of the DESIGN 2016 / $14^{\text {th }}$ International Design Conference, Dubrovnik, Croatia, May 16-19, 2016, The Design Society, Glasgow, pp. 201-210.

Gausemeier, J., Müller, W., Paelke, V., Bauch, J., Shen, Q. and Radkowski, R. (2004), "Virtual Prototyping of SelfOptimizing Mechatronic Systems", Proceedings of DESIGN 2004 / the $8^{\text {th }}$ International Design Conference, Dubrovnik, Croatia, pp. 219-224.

Han, J., Shi, F., Chen, L. and Childs, P. (2017), “The Analogy Retriever-an idea generation tool”, Proceedings of ICED'17 / the 21 International Conference on Engineering Design, Vol. 4, Vancouver, Canada, August 21-25, 2017, The Design Society, Glasgow, pp. 11-20.

Hari, A. and Weiss, M.P. (2003), "Analysis of Risk and Time to Market During the Conceptual Design of New Systems”, Proceedings of ICED'03 / the 14 $4^{\text {th }}$ International Conference on Engineering Design, Stockholm, August 19-21, 2003.

Hari, A., Herscovitz, J., Zonnenshain, A. and Weiss, M.P. (2002), “Application of ICDM for the conceptual design of a new product”, Proceedings of DESIGN 2002 / the $7^{\text {th }}$ International Design Conference, Dubrovnik, Croatia, pp. 647-654.

Horvath, I. (2011), "Theoretical framework for comprehensive abstract prototyping methodology", Proceedings of ICED'11 / the $18^{\text {th }}$ International Conference on Engineering Design, Vol. 2, Copenhagen, Denmark, August 1519, 2011, The Design Society, Glasgow, pp. 108-119.

Husung, S., Holle, W., Hilmer, F. and Weber, C. (2012), "Permanently estimation of assembly costs during product development", Proceedings of DESIGN 2012 / the $12^{\text {th }}$ International Design Conference, Dubrovnik, Croatia, The Design Society, Glasgow, pp. 497-504.

Isaksson, O., Arnarsson, I.Ö., Bergsjö, D., Catic, A., Gustafsson, G. et al. (2017), “Trends, observations and drivers for change in systems engineering design", Proceedings of ICED'17 / the $21^{\text {st }}$ International Conference on Engineering Design, Vol. 3, Vancouver, Canada, August 21-25, 2017, The Design Society, pp. 201-210.

Katzwinkel, T., Jacobs, G., Löwer, M., Schmid, A., Schmidt, W. and Siebrecht, J. (2017), "Functional surfaces as initial product design concept in 3D-CAD-Systems", Proceedings of ICED'17/ the $21^{\text {st }}$ International Conference on Engineering Design, Vol. 6, Vancouver, Canada, August 21-25, 2017, The Design Society, Glasgow, pp. $197-$ 206.

Krause, D. and Eilmus, S. (2011), “A Methodical Approach for Developing Modular Product Families”, Proceedings of ICED'11 / the $18^{\text {th }}$ International Conference on Engineering Design, Vol. 4, Copenhagen, Denmark, August 15-19, 2011, The Design Society, Glasgow, pp. 299-308.

Leroy, Y., Tyl, B., Vallet, F. and Cluzel, F. (2015), "Environmental evaluation of ideas in early phases: a challenging issue for design teams", Proceedings of ICED'15 / the $20^{\text {th }}$ International Conference on Engineering Design, Vol. 1, Milan, Italy, July 27-30, 2015, The Design Society, Glasgow, pp. 117-126.

Li, L.L, Ding, G.H., Feng, N., Wang, M.H. and Ho Y.S. (2009), "Global stem cell research trend: bibliometric analysis as a tool for mapping of trends from 1991 to 2006", Scientometrics, Vol. 80 No. 1, pp. 39-58. https://doi.org/10.1007/s11192-008-1939-5

Lindemann, U. (2007), "A vision to overcome chaotic design for X processes in early phases", Proceedings of ICED'07 / the 16 $6^{\text {th }}$ International Conference on Engineering Design, Paris, France, August 28-31, 2007, The Design Society, Glasgow.

Mabogunje, A., Hansen, P.H., Eris, O. and Leifer, L. (2002), "Product development process ontology", Proceedings of the DESIGN 2002 / $7^{\text {th }}$ International Design Conference, Dubrovnik, Croatia, May 14-17, 2002, pp. 197-202. 
Mao, N., Wang, M.H. and Ho, Y.S. (2010), “A bibliometric study of the trend in articles related to risk assessment published in Science Citation Index", Human and Ecological Risk Assessment, Vol. 16 No. 4, pp. 801-824. https://doi.org/10.1080/10807039.2010.501248

Michailidou, I. and Lindemann, U. (2016), "Managing user experience design: the role of a storykeeper", Proceedings of the DESIGN $2016 / 14^{\text {th }}$ International Design Conference, Dubrovnik, Croatia, May 16-19, 2016, The Design Society, Glasgow, pp. 1773-1782.

Nissl, A. and Lindemann, U. (2005), "Approach for an integrated achievement of the cost target", Proceedings of ICED'05 / 15th International Conference on Engineering Design, Melbourne, Australia, August 15-18, 2005.

Pilemalm, J. and Velin, M. (2003), "Multiproject management from a practitioners point of view", Proceedings of ICED'03 / the 14 $4^{\text {th }}$ International Conference on Engineering Design, Stockholm, August 19-21, 2003

Posner, B., Binz, H. and Roth, D. (2015), "Extension of the Lightweight Design Thinking Tools for the application on more complex problems", Proceedings of ICED'15 / the $20^{\text {th }}$ International Conference on Engineering Design, Vol. 5, Milan, Italy, July 27-30, 2015, The Design Society, Glasgow, pp. 319-328.

Ripperda, S. and Krause, D. (2014), "Costs in modularization approaches: A co-citation analysis", Proceedings of the DESIGN 2014 / $13^{\text {th }}$ International Design Conference, Dubrovnik, Croatia, The Design Society, Glasgow, pp. 965-974.

Roth, M., Mayr, L. and Lindemann, U. (2016), “A Knowledge Framework for Safety Analysis of User-Induced Changes", Proceedings of the DESIGN $2016 / 14^{\text {th }}$ International Design Conference, Dubrovnik, Croatia, May 16-19, 2016, The Design Society, Glasgow, pp. 1553-1562.

Roth, M., Muenzberg, C. and Lindemann, U. (2016), "A Method to Explicate Safety Functions", Proceedings of the DESIGN $2016 / 14^{\text {th }}$ International Design Conference, Dubrovnik, Croatia, May 16-19, 2016, The Design Society, Glasgow, pp. 463-472.

Schleich, B. and Wartzack, S. (2013), "Process-oriented tolerancing - A discrete geometry framework", Proceedings of ICED'13 / the 19 th International Conference on Engineering Design, Vol. 5, Seoul, Korea, August 19-22, 2013.

Shai, O. and Reich, Y. (2003), "Infused design: a brief introduction", Proceedings of ICED'03/the $14^{\text {th }}$ International Conference on Engineering Design, Stockholm, August 19-21, 2003.

Srinivas, K. and Chakrabarti, A. (2007), "Development of a Platform for Supporting Design for Environment", Proceedings of the ICED'07 / the $16^{\text {th }}$ International Conference on Engineering Design, Paris, France, August 28-31, 2007.

Stenholm, D., Stylidis, K., Bergsjö, D. and Söderberg, R. (2017), “Towards robust inter-organizational synergy: Perceived quality knowledge transfer in the automotive industry", Proceedings of ICED'17/ the $21^{\text {st }}$ International Conference on Engineering Design, Vol. 6, Vancouver, Canada, August 21-25, 2017, The Design Society, Glasgow, pp. 11-20.

Theska, R., Frank, T., Hackel, T., Höhne, G. and Lotz, M. (2005), "Methodical Approach for Performance Rating During the Design Process of Precision Machines", Proceedings ICED'05 / the $15^{\text {th }}$ International Conference on Engineering Design, Melbourne, Australia, August 15-18, 2005.

Uchil, P., Chakrabarti, A. and Fantke, P. (2015), "Aiding Designers to make Practitioner-like Interpretations of Life Cycle Assessment Results”, Proceedings of ICED'15 / the $20^{\text {th }}$ International Conference on Engineering Design, Vol. 9, Milan, Italy, July 27-30, 2015, The Design Society, Glasgow, pp. 179-188.

Weidmann, D., Becerril, L., Hollauer, C., Kattner, N. and Lindemann, U. (2017), "A network-based approach to identify lacking coordination using higher order links", Proceedings of ICED'17 / the $21^{\text {st }}$ International Conference on Engineering Design, Vol. 4, Vancouver, Canada, August 21-25, 2017, The Design Society, Glasgow, pp. 405-414.

Weiss, M. P. and Gilboa, Y. (2004), "More on synthesis of concepts as an optimal combination of solution principles", Proceedings of DESIGN 2004 / the $8^{\text {th }}$ International Design Conference, Dubrovnik, Croatia, pp. 1515-1520.

Weiß, S., Berger, B., Jänsch, J. and Birkhofer, H. (2003), “COSECO (Context-Sensitive-Connector)-A logical component for a user- and usage- related dosage of knowledge", Proceedings of ICED'03/the $14^{\text {th }}$ International Conference on Engineering Design, Stockholm, August 19-21, 2003.

Zhang, G.F., Xie, S.D. and Ho, Y.S. (2010), “A bibliometric analysis of world volatile organic compounds research trends," Scientometrics, Vol. 83 No. 2, pp. 477-492. https://doi.org/10.1007/s11192-009-0065-3

Zier, S. and Birkhofer, H. (2013), "Investigating elementary design methods", Proceedings of ICED'13/the $19^{\text {th }}$ International Conference on Engineering Design, Vol. 2, Seoul, Korea, August 19-22, 2013.

Dr.-Ing. Nikola Bursac

Karlsruhe Institute of Technology, Institute of Product Engineering

Kaiserstr. 10, 76131 Karlsruhe, Germany

Email: Nikola.Bursac@kit.edu 